\title{
In memory of Prof. Sergio Mancini
}

\section{G Botta 1}

${ }^{1}$ Director of Phlebological Unit of the Siena Hospital

submitted: Jul 20, 2017, accepted: Jul 20, 2017, EPub Ahead of Print: Jul 24, 2017

DOI: 10.24019/jtavr.28 - Corresponding author: Prof. Giuseppe Botta, giuseppe.botta@unisi.it

(C) 2017 Fondazione Vasculab impresa sociale ONLUS. All rights reserved.

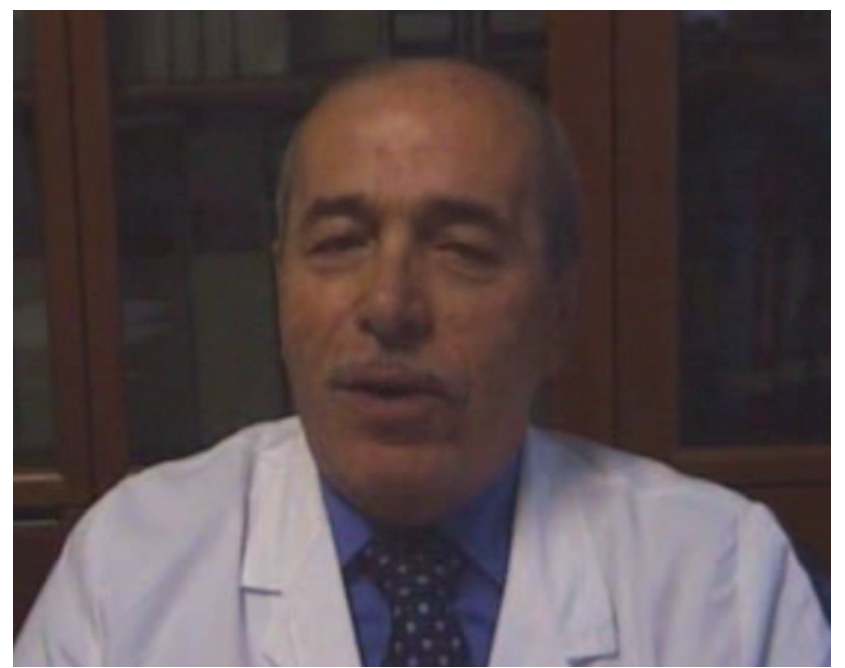

Figure 1 - Prof. Sergio Mancini

Sergio Mancini left us after a long illness in the night between 26 and 27 April, 2017.

He was born in Livorno on October 19, 1937.

After graduating at the high school Carducci of Milan, he matriculated to the Faculty of Medicine of the Naples University, where his family had moved for work.

Graduated in Medicine and Surgery at Naples University in March 1964, he came to Siena, where he began his academic career in the surgical school of Prof. Luigi Gallone.

Winner of a university chair of surgery, Sergio Mancini was called unanimously by the Faculty of Medicine and Surgery of the Siena University to cover the Chair of General Surgery from November 1, 1995.
Later he became Director of the Department of General Surgery at the Siena Hospital and also Director of the School of Specialization in General Surgery after the retirement of his teacher, Prof. Luciano Lorenzini. In this role he became at the end of the last century and the beginning of the present century one of the most authoritative representatives of the Siena Surgical School.

Master of Life and Science, man of great humanity and sensibility with strong charisma, he was a talented general surgeon and a great teacher, forming many students, some of whom later became academics and specialists in Phlebolymphology of the highest national reputation.

Both in chair and in life he has always shown a great and eclectic personality, transferring to the students, to the doctors of his group and to the patients an extraordinary authority, which has been the emblem of his professional image.

But his passion were the diseases of the veins and the lymphatic vessels, both in terms of care and research. In 1985 Sergio Mancini founded at the Siena University the Center of Phlebolymphology, that soon became one of the most important in the world, and he surrounded himself strategically with a group of young doctors, to whom he transmitted the passion for the care of patients suffering from diseases of the veins and lymphatic vessels.

Finally, over the three-year period 1997-1999, Prof. Sergio Mancini became President of the Italian Society of Phlebolymphology and in this role he contributed greatly as a founding member to the birth of the Italian College of Phlebology, which had to become in his intentions the common house of all Italian Phlebologists.

Known and much appreciated as specialist in the international context, he left many friends and colleagues in 
various parts of the world, such as Argentina, Brazil, United States, France.

Dear professor, I do not know if You can still be interested in earthly things from the place where You are now, but if You can read these few lines, know that You left in me - Your beloved pupil as You often told me - an unbridgeable void and an indelible memory.

\section{Giuseppe Botta}

Director of Phlebological Unit of the Siena Hospital 